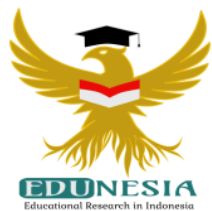

\title{
The Correlation Between Work Motivation and Work Discipline on Teacher Performance
}

\author{
Syafe'i i'; Alhadi Yan Putra ${ }^{2}$; Nur Ahyani ${ }^{3}$ \\ 1,2,3 Department of Education Management, Universitas PGRI Palembang, Indonesia \\ ${ }^{1}$ Corresponding Email: safeilengkiti76@yahoo.com, Phone Number : 0823 xxxx xxxx
}

\author{
Article History: \\ Received: Jan 13, 2021 \\ Revised: Mar 15, 2021 \\ Accepted: Mar 21, 2021 \\ Online First: Mar 26, 2021
}

\section{Keywords:}

Work Discipline, Work

Motivation, Teacher

Performance.

\section{Kata Kunci:}

Disiplin Kerja, Kinerja Guru, Motivasi Kerja.

\section{How to cite:}

Syafe'i, S., Putra, A.Y., \& Ahyani, N. (2021). The Correlation Between Work Motivation and Work Discipline on Teacher Performance. Edunesia: Jurnal Ilmiah Pendidikan, 2 (2): 424-443.

This is an open access article under the $C C-B Y-N C-N D$ license

\begin{abstract}
This study aims to determine the correlation between work motivation and work discipline on teacher performance. The formulation of the problems in this study: (1) is there a correlation between work motivation and teacher performance?, (2) is there a correlation between work discipline and teacher performance?, (3) is there a correlation between work motivation and work discipline on teacher performance. This type of research is descriptive quantitative. The sample in this study amounted to 74 students. Data collection techniques in the form of tests and documentation. The instrument used was a test sheet. The theories used are teaching and learning strategy theory and learning evaluation theory. The results of this study. Based on the respondents' perceptions of work motivation, a score range of 116-150 was obtained, with a total score of 20409 and an average score of 130.79 which in this case was categorized as quite good. Respondents' perceptions about the effect of work discipline on teacher performance obtained a score range of 107 - 151, with a total score of 20191.00 and an average score of 134.43 which is in the good category. The degree of influence of the work motivation variable $\left(X_{1}\right)$ and the work discipline variable $\left(\mathrm{X}_{2}\right)$ on teacher performance $(\mathrm{Y})$ was 0.73 or $73 \%$. This shows that the teacher's performance $(\mathrm{Y})$ is jointly (simultaneously) influenced by the work motivation variable $\left(X_{1}\right)$ and the work discipline variable $\left(X_{2}\right)$ by $73 \%$ while the remaining $27 \%$ is influenced by other factors outside the equation model.
\end{abstract}

Abstrak: Penelitian ini bertujuan untuk mengetahui hubungan motivasi kerja dan disiplin kerja terhadap kinerja guru. Rumusan masalah dalam penelitian ini: (1) apakah terdapat hubungan motivasi kerja terhadap kinerja guru?, (2) apakah terdapat hubungan disiplin kerja terhadap kinerja guru?, (3) apakah terdapat hubungan yang simultan motivasi kerja dan disiplin kerja terhadap kinerja guru. Jenis penelitian ini adalah deskriptif kuantitatif. Sampel dalam penelitian ini berjumlah 74 siswa. Teknik pengumpulan data berupa tes dan dokumentasi. Instrument yang digunakan adalah lembar tes. Teori yang digunakan adalah teori strategi belajar mengajar dan teori evaluasi pembelajaran. Hasil penelitian ini Berdasarkan persepsi responden tentang motivasi kerja, diperoleh rentang skor 116 - 150, dengan jumlah skor 20409 dan skor rata-rata 130,79 yang dalam hal ini termasuk kategori cukup baik. Persepsi responden tentang pengaruh disiplin kerja terhadap kinerja guru diperoleh rentang skor 107 - 151, dengan jumlah skor 20191,00 dan skor rata-rata 134,43 adalah termasuk kategori baik. Derajat pengaruh variabel motivasi kerja $\left(\mathrm{X}_{1}\right)$ dan variabel disiplin kerja $\left(\mathrm{X}_{2}\right)$ terhadap kinerja guru $(\mathrm{Y})$ sebesar 0,73 atau $73 \%$. Angka ini menunjukan bahwa kinerja guru $(Y)$ secara bersama-sama (simultan) dipengaruhi oleh variabel motivasi kerja $\left(X_{1}\right)$ dan variabel disiplin kerja $\left(X_{2}\right)$ sebesar $73 \%$ sedangkan sisanya $27 \%$ dipengaruhi oleh faktor-faktor lain di luar model persamaan tersebut. 


\section{A. Introduction}

The Indonesian government, to improve education for its citizens, continuously carries out various activities and provides supporting facilities, including the enactment of Law no. 14 of 2005 concerning teachers and lecturers. As stated in the general explanation of Law no. 14 of 2005, the Preamble of the 1945 Constitution of the Republic of Indonesia states that the purpose of national education is to protect the entire nation and all the blood of Indonesia and to promote public welfare, educate the nation's life, and participate in implementing world order based on independence, eternal peace, and social justice. To realize these national goals, education is a very determining factor.

Human resources are the main requirements for the realization of a developed nation and country (Isdawel et al, 2020). Regardless of the size of natural resources, the available capital and infrastructure, in the end, it is only in the hands of reliable human resources that the target of the nation and state development can be achieved. In this perspective of thinking, a nation cannot achieve progress without a good education system (Budiman, 2017).

Human resources are a source for achieving competitive advantage because of their ability to convert other resources (money, machines, methods and materials) into results (products/services) (Nasution \& Aliffioni, 2018). Competitors can emulate other sources such as technology and capital but not unique human resources. Employees have a strategic role in the company, namely as thinkers, planners, and controllers of company activities because they have the talent, energy and creativity that are needed by the company to achieve goals (Permanasari, 2013). Almasri (2016) argues that human resource management is a process that includes everything related to the organization and the people who run it.

Education is the basic capital for creating human resources. The main world of education is school (Kemal et al, 2019). Schools are one of the alternative educational service institutions. School as an institution certainly has a vision, mission, goals and functions (Maujud, 2018). To carry out the mission, realize the vision, achieve goals, and carry out its functions, schools need professional staff, organizational work procedures and supporting resources both financially and non-financially (Kemal \& Rahmatullah, 2015).

School as a system has components that are related to each other and contribute to achieving goals. These components are students, curriculum, teaching materials, teachers, school principals, other education personnel, environment, facilities, learning processes and outputs. All these components must develop according to the demands of the times and environmental changes that occur around them. To develop, of course, there must be a process of change. This development should start from things that cause the organization to not function as well as expected (Kurniah et al, 2019).

In the conception of institutional development, there is an effort to introduce changes in the way an institution is organized, the structure, processes and systems of the institution concerned so that it can better fulfil its mission. Therefore, changes that occur in school institutions must include all components in it.

These changes occur in the structure, processes, workforce and systems of an institution as well as the change process itself, regarding how schools as institutions are organized so that they can carry out their mission well. In the process of change, individual organizations and institutions improve their abilities and performance about their goals, resources, and environment. The change will not take place without the support of human resources who are assets that can contribute more to achieving organizational goals. 
The teacher is one of the human resources who are in school. The performance of teachers in schools has an important role in achieving school goals. Performance problems are under the spotlight of various parties, government performance will be felt by the community and teacher performance will be felt by students or parents of students. Various attempts were made to achieve good performance. The government's attention to education has been socialized, the education budget mandated by the $20 \%$ law has begun to be implemented. Then the teacher's performance will of course be the concern of all parties. Teachers must be truly competent in their fields and teachers must also be able to serve optimally. Optimal teacher performance is related to various factors, both internal and external.

The primary school in Ogan Komering Ulu District consists of public and private schools. One of the indicators of a school that is considered successful is the acquisition of high national exam scores and maximum passing rates. The school with the highest national examination score and an annual passing rate of $100 \%$ is always considered successful and will gain the trust of the community. Though not necessarily student success is the result of teacher performance.

The success of school achievement is determined by various factors, including the work motivation of a teacher. A teacher can work professionally if he has high motivation. Employees/teachers who have high motivation will usually carry out their duties energetically and energetically because there are certain motives or goals behind these actions. The motive is the driving factor that gives him strength so that he is willing to work hard. Juniarti, et al (2020) state that works discipline as the implementation of management to reinforce the guidelines is seen as closely related to performance.

\section{B. Method}

This research method is descriptive quantitative research because this research is focused on solving the problem under study by describing an object of research, namely by looking for data related to work motivation $\left(X_{1}\right)$, work discipline $\left(X_{2}\right)$ with the dependent variable namely teacher performance $(Y)$, where the data obtained from a sample of the study population is then analyzed according to the statistical method used and then interpreted.

The population and sample in this study were all teachers of SD Negeri 74 OKU, totalling 25 people including the principal and non-permanent teachers. The following are the teachers who teach at SD Negeri 74 OKU. The data analysis technique used in this research is the assumption test which consists of the data normality test, homogeneity test, and linearity test. While the hypothesis test consists of the correlation product-moment, test and t-test. Assumption testing and hypothesis testing are techniques that must be used to analyze quantitative data. As for knowing the relationship between work motivation and work discipline on teacher performance using the ANOVA formula with a significance level of $5 \%$. If or at the $5 \%$ and $1 \%$ significance levels are equal to or greater than or then the two variables have a positive correlation, and if the results are obtained then the zero hypothesis significance level is rejected, while the alternative hypothesis is accepted, it means that there is indeed a significant positive correlation between the variables $\mathrm{X}$ and $\mathrm{Y}$ variables. 


\section{Result and Discussion}

\section{Results}

\section{a. Description of Research Data}

Data on respondents' perceptions about work motivation variables were obtained through a questionnaire with 25 respondents in the following table.

Table 1. Descriptive statistics of work motivation variables

\begin{tabular}{|l|r|}
\hline N & Valid \\
Mean & 104 \\
Std. Error of & \\
Mean & 130,79 \\
Median &, 571 \\
Mode & \\
Std. Deviation & 130,00 \\
Variance & 130 \\
Range & 7,126 \\
Minimum & 50,774 \\
Maximum & 31 \\
Sum & 116 \\
\hline
\end{tabular}

The highest score is 147 , the lowest score is 116 , mean 130.79 , median 130.00 , mode 130, and standard deviation is 7.126. The categories to find out respondents' perceptions of work motivation are not very good, not good, good enough, good, and very good, can be seen in the table below.

Table 2. Perception category work motivation

\begin{tabular}{c|ccc}
\hline Score & Category & Frequency & Percentage \\
\hline $116-122$ & very bad & 12 & 11,53 \\
$123-129$ & bad & 18 & 17,5 \\
$130-136$ & enough & 39 & 37,5 \\
$137-143$ & good & 21 & 20,19 \\
$144-150$ & very good & 14 & 13,45 \\
\hline
\end{tabular}

It is known that respondents' perceptions about work motivation are each in the very bad category with a frequency of 12 or $11.53 \%$. The category is bad with a frequency of 18 or $17.5 \%$. enough category has a frequency of 39 or $37.5 \%$. The good category has a frequency of 21 or $20.19 \%$. Very good category has a frequency of 14 or $13.45 \%$. The above data can be seen in the histogram below. 


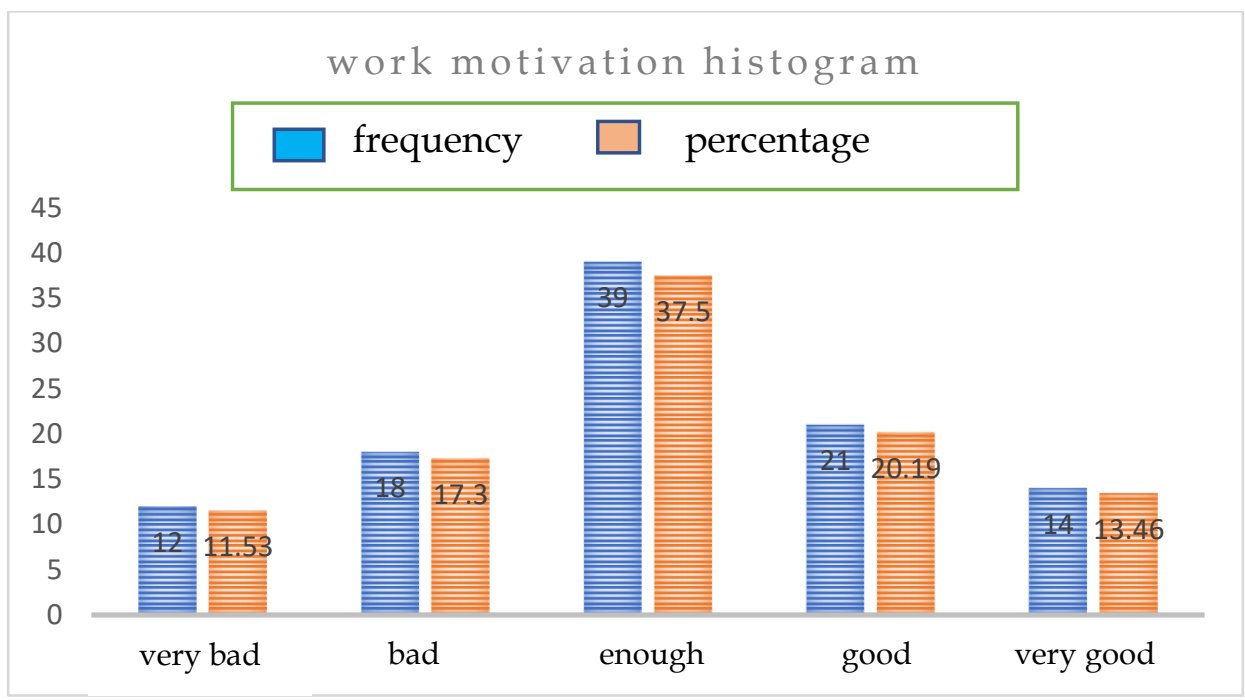

Figure 1. Work motivation histogram

The histogram variable of work motivation can be seen that the highest result is a score range of $130-136$ or $37.5 \%$ indicating that the respondent's perception of work motivation is quite good. While the lowest was the range $116-122$ or $11.53 \%$ indicating that the respondent's perception of work motivation was very bad. The dimensional factor analysis of the work motivation variable obtained from the questionnaire is shown in the following table.

Table 3. Table analysis of work motivation variables

\begin{tabular}{|r|r|r|}
\hline & \multicolumn{1}{|c|}{ Initial } & Extraction \\
\hline X1.1 & 1,000 &, 695 \\
X1.2 & 1,000 &, 691 \\
X1.3 & 1,000 &, 966 \\
X1.4 & 1,000 &, 372 \\
X1.5 & 1,000 &, 651 \\
X1.6 & 1,000 &, 936 \\
X1.7 & 1,000 &, 701 \\
\hline
\end{tabular}

The highest analysis value for the warmth indicator $(\mathrm{X} 1.3)$ is 0.966 and the lowest is for the support indicator (X1.4) of 0.372 while for other indicators: responsibility (X1.1) is equal to 0.695 ; sense of belonging (X1.2) of 0.91 ; conflict (X1.5) of 0.651; award (X1.6) of 0.936; and commitment (X1.7) of 0.701 .

\section{b. Work Dicipline}

Data on respondents' perceptions about work discipline variables were obtained through a questionnaire with 25 respondents in the following table. 
Table 4. Descriptive Statistics of Work Motivation Variables

\section{Statistics}

Motivation Variables

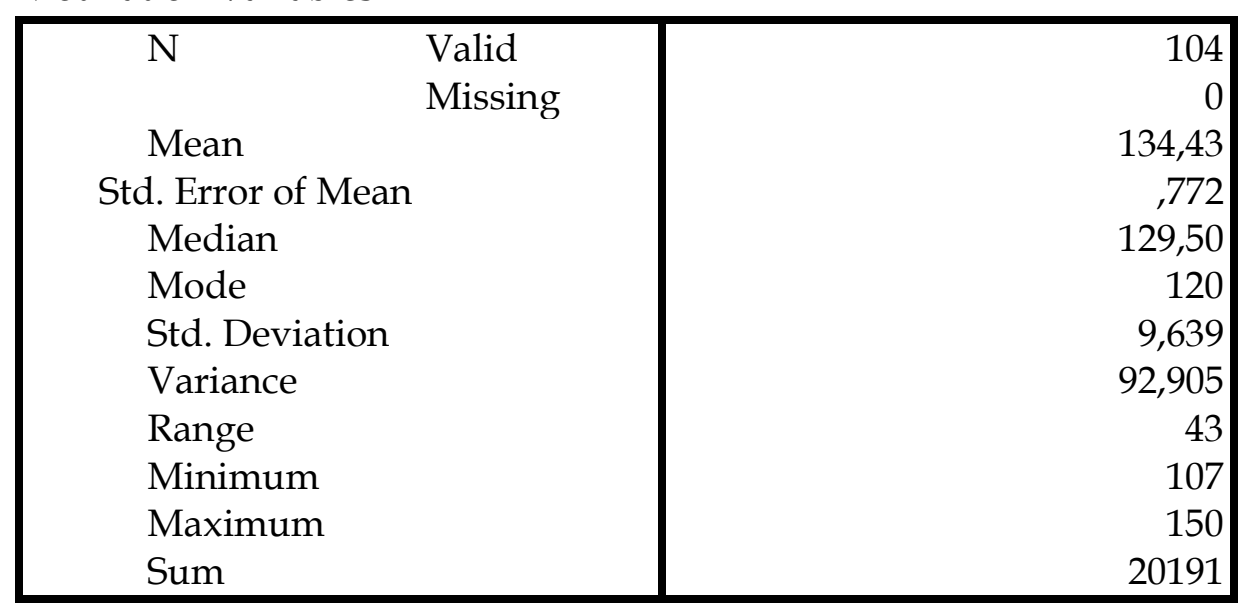

It can be explained that of the 104 respondents who entered, the highest score was 150 , the lowest score was 107.00 , the mean 134.43 , the median 129.50 , mode 120 , standard deviation 9.639. Categories to determine respondents' perceptions of work discipline are: very bad, bad, enough, good, and very good.

Table 5. Categories of perceptions of work discipline

\begin{tabular}{cccc}
\hline Score & Category & Frequency & Percentage \\
\hline $107-115$ & very bad & 11 & 10,57 \\
$116-124$ & bad & 13 & 12,5 \\
$125-133$ & enough & 24 & 23,07 \\
$134-142$ & good & 43 & 41,34 \\
$143-151$ & very good & 13 & 12,5 \\
& Total & 104 & 100 \\
\hline
\end{tabular}

It is known that respondents' perceptions of teacher work discipline have several categories. Very bad category has a frequency of 11 or $10.57 \%$. The bad category has a frequency of 13 with a percentage of $12.5 \%$. Enough category has a frequency of 24 with a percentage of $23.07 \%$. The good category has a frequency of 43 with a percentage level of $41.34 \%$. Very good category has a frequency of 13 with a percentage of $12.5 \%$. The data is in the form of a bar chart as follows. 


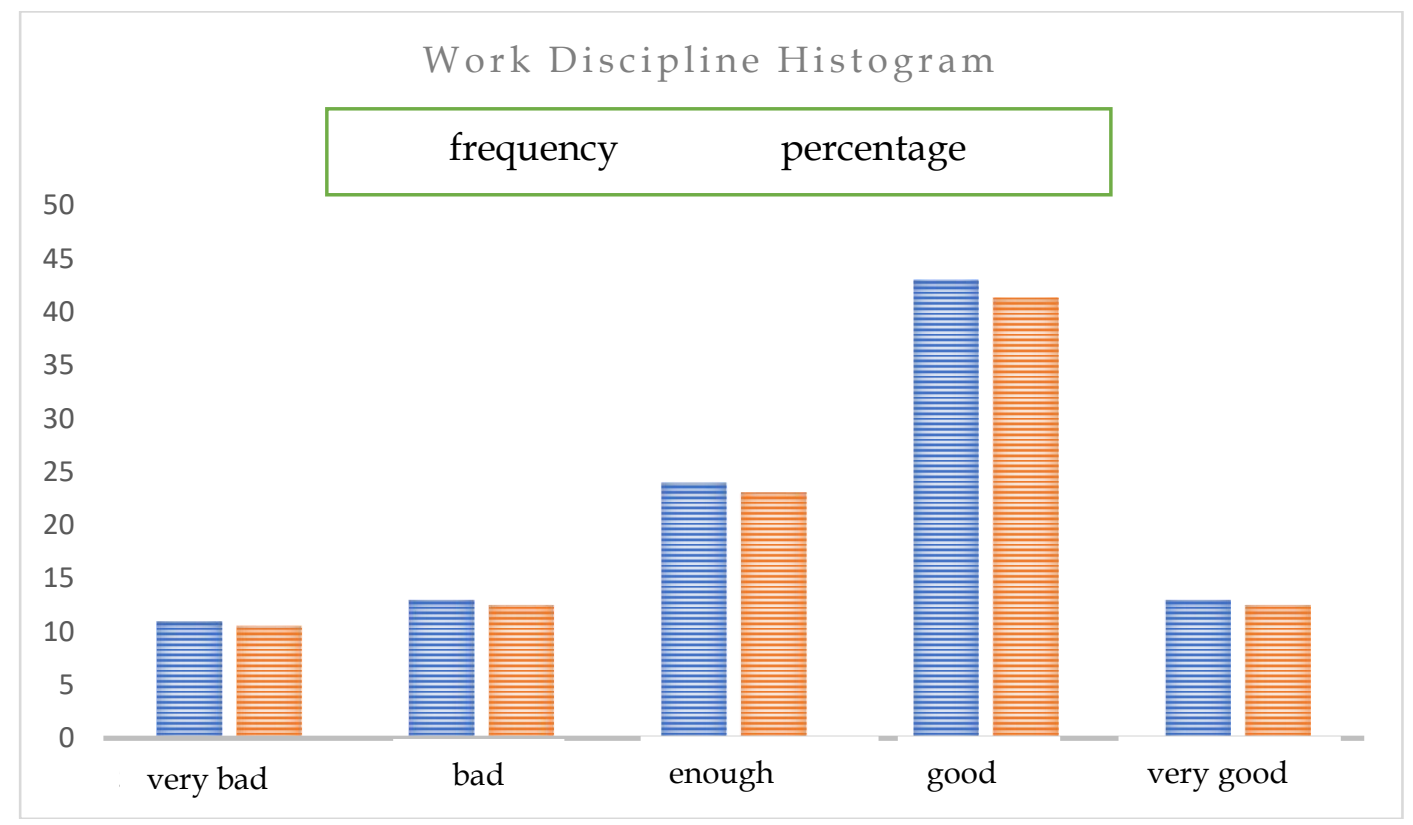

Figure 2. Work discipline variable histogram

It can be seen that the highest result is the score range $134-142$ or $41.34 \%$ indicating that the respondent's perception of work discipline is good. While the lowest is the range $107-115$ or $10.57 \%$ indicating that the respondent's perception of work discipline is very bad. The factor analysis on the variable of work discipline obtained from the respondents' questionnaire is shown in the following table.

Table 6. Table analysis of work motivation variables

\begin{tabular}{|r|l|r|}
\hline & Initial & Extraction \\
\hline X2.1 & 1,000 &, 634 \\
X2.2 & 1,000 &, 727 \\
X2.3 & 1,000 &, 600 \\
X2.4 & 1,000 &, 319 \\
X2.5 & 1,000 &, 532 \\
X2.6 & 1,000 &, 673 \\
X2.7 & 1,000 &, 687 \\
X2.8 & 1,000 &, 625 \\
\hline
\end{tabular}

The highest analysis value for the individual recognition indicator $(X 2.2)$ is 0.727 and the lowest for the leader loyalty indicator (X2.4) is 0.319 while for other indicators: advancement opportunities (X2.1) amounting to 0.634; job security (X2.3) of 0.600 job security $(\mathrm{X} 2.5)$ of 0.532 achievement $(\mathrm{X} 2.6)$ of 0.673 of promotion $(\mathrm{X} 2.7)$ of 0.687 salary / wages $(\mathrm{X} 2.8)$ of 0.625 . 


\section{c. Teacher Performance} table.

Data on respondents' perceptions about teacher performance are in the following

Table 7. Teacher performance variable description statistics

Statistics
Teacher performance
\begin{tabular}{|l|r|}
\hline N Valid & 104 \\
Missing & 0 \\
Mean & 53,76 \\
Std. Error of Mean &, 368 \\
Median & 51,00 \\
Mode & 48 \\
Std. Deviation & 4,602 \\
Variance & 21,179 \\
Range & 19 \\
Minimum & 41 \\
Maximum & 60 \\
Sum & 7918 \\
\hline
\end{tabular}

The highest score is 60 , the lowest score is 41 , mean 53.76 , median 51.00, mode 48.00, and standard deviation is 4.602. Categories to find out respondents' perceptions of teacher performance, namely: very bad, bad, enough, good, and very good, can be seen in the table below:

Table 8. Teacher performance categories $(\mathrm{Y})$

\begin{tabular}{cccc}
\hline Score & Category & Frequency & Percentage \\
\hline $41-44$ & very bad & 10 & 9,61 \\
$45-48$ & Bad & 12 & 21,15 \\
$49-52$ & enough & 16 & 15,38 \\
$53-56$ & Good & 42 & 40,38 \\
$57-60$ & very good & 24 & 13,46 \\
& Total & 104 & 100 \\
\hline
\end{tabular}

It can be seen that the respondents' perceptions of teacher performance each have a very bad category of 10 with a percentage of $9.01 \%$, the bad category has a frequency of 22 with a percentage of $21.15 \%$, the category is enough having a frequency of 16 with a percentage of $15.38 \%$, the good category has a frequency of 42 with a percentage of 40.38 , and the very good category has a frequency of 14 with a percentage of 13.46 . Thus, it can be concluded that the teacher's performance is in a good category. Teacher performance categories can be presented in the form of a histogram below. 


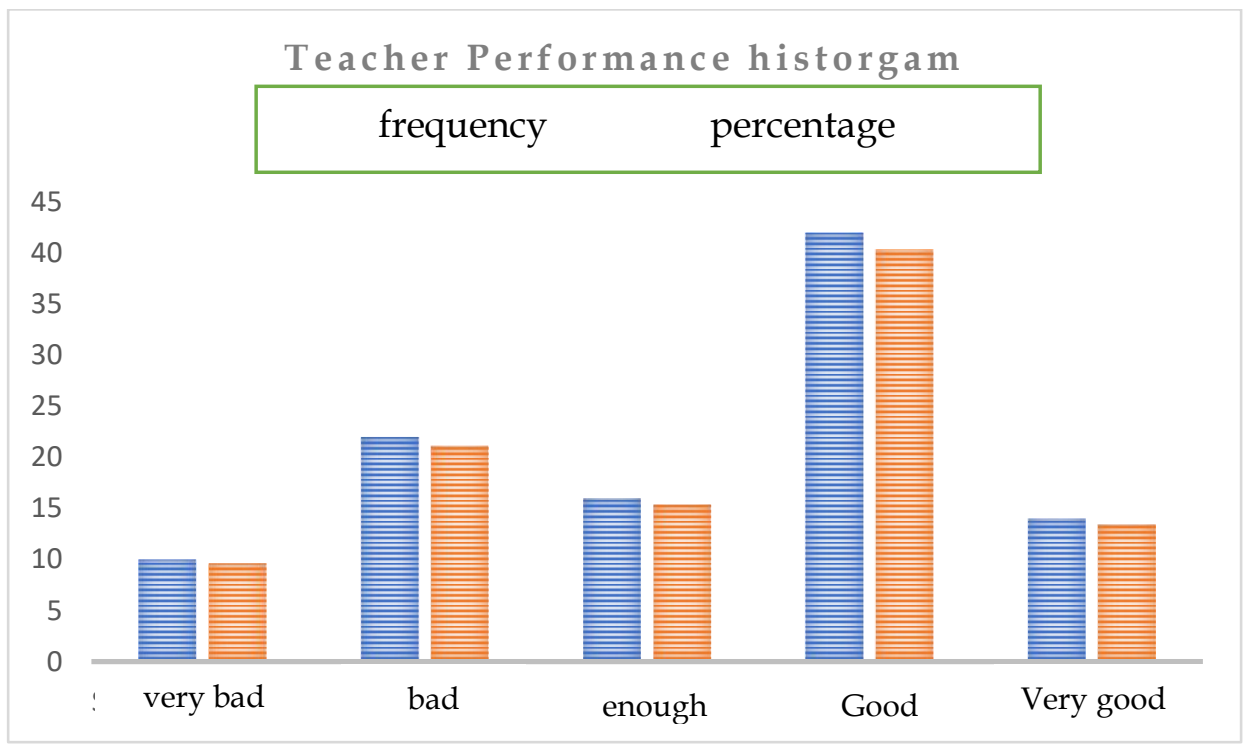

Figure 3. Histogram of teacher performance variables

The teacher performance histogram above shows that the highest result is a score range of $53-56$ or $40.38 \%$ indicating that the respondent's perception of teacher performance is good. The lowest score is the range $41-44$ or $9.61 \%$ indicating that the respondent's perception of teacher performance is very bad. Dimensional factor analysis data on teacher performance variables obtained from the respondent's questionnaire is shown in the following table.

Table 9. Table analysis of teacher performance variable factors

Communalities

\begin{tabular}{|c|c|c|}
\hline & Initial & Extraction \\
\hline $\mathrm{Y} 1$ & 1,000 & ,739 \\
\hline$Y 2$ & 1,000 & 675 \\
\hline Y3 & 1,000 & 710 \\
\hline
\end{tabular}

The value of factor analysis for the learning planning dimension $\left(\mathrm{Y}_{1}\right)$ is 0.739 ; the dimensions of the learning process $\left(\mathrm{Y}_{2}\right)$ of 0.675 ; and the dimensions of the assessment $\left(\mathrm{Y}_{3}\right)$ of 0.710 .

\section{d. Hypotesis Testing \\ 1) Regression Analysis \\ a) Simple Linear Regression Analysis}

Simple linear regression analysis to determine the effect of work motivation variables $\left(X_{1}\right)$ on teacher performance variables $(Y)$. The results of the simple linear regression analysis for the variable $\left(\mathrm{X}_{1}\right)$ on the variable $(\mathrm{Y})$ using the SPSS program are as follows. 
Table 10. Variable correlation test results $\left(\mathrm{X}_{1}\right)$ and $(\mathrm{Y})$

\begin{tabular}{|rl|r|r|}
\multicolumn{4}{c|}{ Correlations } \\
\hline \multirow{2}{*}{$\mathrm{X} 1$} & $\mathrm{X}_{1}$ & $\mathrm{Y}$ \\
\hline & Pearson Correlation & 1 &, $532^{* *}$ \\
& Sig. (2-tailed) & &, 000 \\
& $\mathrm{~N}$ & 104 & 104 \\
& Pearson Correlation &, $532^{* *}$ & 1 \\
$\mathrm{Y}$ & Sig. (2-tailed) &, 000 & \\
& $\mathrm{~N}$ & 104 & 104 \\
\hline
\end{tabular}

**. Correlation is significant at the 0.01 level (2-tailed).

The correlation coefficient value between work motivation and teacher performance is 0.532 , it can be concluded that work motivation and teacher performance have a strong relationship which is indicated by the correlation value close to +1 . The significance value of $0.000<0.05$, it can be concluded that there is a significant relationship between the two variables. A positive sign indicates that the correlation between work motivation and teacher performance is a "directly proportional" relationship, meaning that the greater the value of work motivation, the higher the value of teacher performance. So it can be concluded that the relationship between work motivation and teacher performance is very strong, significant, and unidirectional. Furthermore, hypothesis 1 is tested by looking at the following table.

Table 11. ANOVA table regression test $X_{1}$ to $Y$

ANOVA $^{b}$

\begin{tabular}{|l|r|r|r|c|c|}
\hline \multicolumn{1}{|c|}{ Model } & $\begin{array}{c}\text { Sum of } \\
\text { Squares }\end{array}$ & df & Mean Square & F & Sig. \\
\hline 1 & 1793.6 & 1 & 1793.6 & 1 & \\
Regression & 05 & & 05 & 85.486 & $000^{\mathrm{a}}$ \\
Residual & 1489.1 & 15 & 9.670 & & \\
& 39 & 4 & & & \\
Total & 3282.7 & 15 & & & \\
\hline
\end{tabular}

a. $\quad$ Predictors: (Constant),Work Motivation

b. Dependent Variable: Teacher Performance

Table 11 above shows that $\mathrm{F}_{\text {count }}=185.486>\mathrm{F}_{\text {table }}=3.06$ with a probability level of significance $0.000<0.05$ or sig $=0.000=0 \%<5 \%$ means reject $\mathrm{H}_{0}$ and accept $\mathrm{H}_{\mathrm{a}}$, thus the regression model used for this study is significant, meaning that the work motivation variable $\left(X_{1}\right)$ has a significant effect on the teacher performance variable $(Y)$. The next process is to determine the magnitude of the influence of the work motivation variable $\left(X_{1}\right)$ on the teacher performance variable $(Y)$, namely the coefficient of determination $\left(R_{2}\right)$ by looking at the R Square value in the output model summary table below: 
Table 12. Table summary of regression test $X_{1}$ to $Y$

Model Summary

\begin{tabular}{|r|c|r|r|r|}
\hline Model & $\mathrm{R}$ & $\mathrm{R}$ Square & $\begin{array}{c}\text { Adjusted R } \\
\text { Square }\end{array}$ & $\begin{array}{c}\text { Std. Error of the } \\
\text { Estimate }\end{array}$ \\
\hline 1 & $.739 \mathrm{a}$ & .546 & .543 & 3.110 \\
\hline
\end{tabular}

a. Predictors: (Constant), Work Motivation

It explains the magnitude of the correlation value (r) which is equal to 0.739 and the determination coefficient $\left(\mathrm{R}_{2}\right)$ is 0.546 which implies that the influence of the work motivation variable $\left(\mathrm{X}_{1}\right)$ on the dependent variable teacher performance $(\mathrm{Y})$ is $54.3 \%$, while the remaining $45.7 \%$ is influenced by other variables. Furthermore, the $t$ test is carried out according to the following table.

Table 13. Coefficeints regresi $X_{1}$ to $Y$

\section{Coefficients ${ }^{a}$}

\begin{tabular}{|c|c|c|c|c|c|}
\hline \multirow[b]{2}{*}{ Model } & \multicolumn{2}{|c|}{$\begin{array}{l}\text { Unstandardized } \\
\text { Coefficients }\end{array}$} & \multirow{2}{*}{\begin{tabular}{|c|}
$\begin{array}{c}\text { Standardized } \\
\text { Coefficients }\end{array}$ \\
Beta
\end{tabular}} & \multirow[b]{2}{*}{$\mathrm{t}$} & \multirow[b]{2}{*}{ Sig. } \\
\hline & B & Std. Error & & & \\
\hline 1 (Constant) & -8.745 & 4.376 & & -1.998 & .047 \\
\hline Motivasi_Kerja & .458 & .034 & .739 & 13.619 & .000 \\
\hline
\end{tabular}

a. Dependent Variable: Performance Teacher

It can be seen that the coefficient of constant (a) is -8.745 and work motivation $\left(b_{1}\right)$ is 0.458 so that the regression equation can be written: $\hat{Y}=-8,745+0.458 \mathrm{X}_{1}$. The coefficient $\mathrm{b}_{1}$ is called the efficiency of the regression direction, which states the average change in the $Y$ variable for every change in the $X_{1}$ variable is one unit. This change is an increase if $b_{1}$ is positive and a decrease if $b_{1}$ is negative.

Simple linear regression analysis to determine the effect of work discipline variables $\left(\mathrm{X}_{2}\right)$ on teacher performance variables $(\mathrm{Y})$. The results of the simple linear regression analysis for the variable $\left(\mathrm{X}_{2}\right)$ on the variable $(\mathrm{Y})$ using the SPSS program are as follows.

Table 14. Result of correlation test of variable $X_{2}$ to $Y$

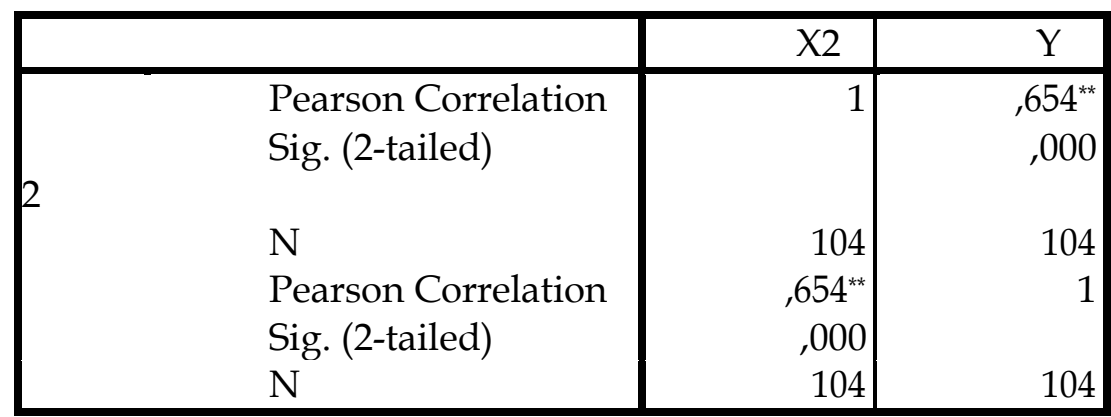


**. Correlation is significant at the 0.01 level (2-tailed).

The correlation coefficient value between work discipline and teacher performance is 0.654 , it can be concluded that between work discipline and teacher performance has a strong relationship which is indicated by the correlation value close to +1 . The significance value of $0.000<0.05$, it can be concluded that there is a significant relationship between the two variables. A positive sign indicates that the correlation between work discipline and teacher performance is a "directly proportional" relationship, meaning that the greater the value of work discipline, the higher the value of teacher performance. So it can be concluded that the relationship between work discipline and teacher performance is very strong, significant, and unidirectional. Furthermore, hypothesis 2 is tested by looking at the following table.

Table 15. ANOVA table regression test $X_{2}$ to $Y$

ANOVA $^{b}$

\begin{tabular}{|c|c|c|c|c|c|}
\hline Model & $\begin{array}{c}\text { Sum of } \\
\text { Squares }\end{array}$ & Df & $\begin{array}{c}\text { Mean } \\
\text { Square }\end{array}$ & F & Sig. \\
\hline 1 Regression & 2402.041 & 1 & 2402.041 & 420.022 & $.000^{a}$ \\
Residual & 880.702 & 154 & 5.719 & & \\
Total & 3282.744 & 155 & & & \\
\hline
\end{tabular}

a. Predictors: (constant), work discipline

b. Dependent Variable: teacher

performance

It can be seen that $\mathrm{F}_{\text {count }}=420.022>\mathrm{F}_{\text {table }}=3.06$ with a significance level of probability $0.000<0.05$ or sig $=0.000=0 \%<5 \%$ means reject $\mathrm{H}_{0}$ and accept $\mathrm{H}_{\mathrm{a}}$, thus the regression model used for this study is significant This means that the work discipline variable $\left(\mathrm{X}_{2}\right)$ has a positive and significant effect on the teacher performance variable $(Y)$.

The next process is to determine the magnitude of the effect of the work discipline variable $\left(\mathrm{X}_{2}\right)$ on the teacher performance variable $(\mathrm{Y})$, namely the coefficient of determination $\left(\mathrm{R}_{2}\right)$ by looking at the $\mathrm{R}$ Square value in the summary model output table below.

Table 16. Table summary of $\mathrm{X}_{2}$ to $\mathrm{Y}$ regression test

model Summary

\begin{tabular}{|r|r|r|r|r|}
\hline Model & \multicolumn{1}{|c|}{$\mathrm{R}$} & R Square & \multicolumn{1}{|c|}{$\begin{array}{c}\text { Adjusted R } \\
\text { Square }\end{array}$} & $\begin{array}{c}\text { Std. Error of the } \\
\text { Estimate }\end{array}$ \\
\hline 1 & .855 & .732 & .730 & 2.391 \\
\hline
\end{tabular}

a. Predictors: (Constant), Motivation to teach

It explains the magnitude of the correlation value (r) which is equal to 0.855 and obtained a determination coefficient $\left(\mathrm{R}_{2}\right)$ of 0.732 which implies that the influence of the work discipline variable $\left(\mathrm{X}_{2}\right)$ on the dependent variable teacher performance $(\mathrm{Y})$ is $73.2 \%$, 
while the remaining $26.8 \%$ is influenced by other variables. Furthermore, the $t$ test is carried out according to the following table.

Table 17. Coefficients regression $X_{2}$ against $Y$

\section{Coefficients ${ }^{\mathrm{a}}$}

\begin{tabular}{|c|c|c|c|c|c|}
\hline \multirow[b]{2}{*}{ Model } & \multicolumn{2}{|c|}{$\begin{array}{c}\text { Unstandardized } \\
\text { Coefficients }\end{array}$} & $\begin{array}{c}\text { Standardized } \\
\text { Coefficients } \\
\end{array}$ & \multirow[b]{2}{*}{$\mathrm{t}$} & \multirow[b]{2}{*}{ Sig. } \\
\hline & B & Std. Error & Beta & & \\
\hline $1 \quad$ (Constant) & 2.105 & 2.586 & .855 & .814 & .417 \\
\hline Teacher_Performance & .408 & .020 & & 20.494 & .000 \\
\hline
\end{tabular}

a. Dependent Variable: Teacher Performance

It can be seen that the coefficient of Constant (a) is 2.105 and the coefficient of work discipline $\left(b_{2}\right)$ is 0.408 so that the regression equation can be written: $\hat{Y}=-2.105+0.408 \mathrm{X}_{2}$. every change in the $X_{2}$ variable is one unit. This change is an increase if $b_{1}$ is positive and a decrease if $b_{1}$ is negative.

\section{b) Multiple Linear Regression Analysis}

Multiple linear regression analysis to determine the effect of work motivation $\left(X_{1}\right)$ and work discipline $\left(\mathrm{X}_{2}\right)$ variables simultaneously on teacher performance variables $(Y)$ The results of multiple linear regression analysis of work motivation variables $\left(X_{1}\right)$ and work discipline variables $\left(\mathrm{X}_{2}\right)$ simultaneously on teacher performance variable $(\mathrm{Y})$ using the SPSS program as follows:

Table 18. Coefficients regression $X_{1}$ and $X_{2}$ simultaneously against $Y$

\section{Correlations}

\begin{tabular}{|l|r|r|r|}
\hline & teacher_performance & work_motivation & work_discipline \\
\hline $\begin{array}{l}\text { Pearson } \\
\text { Teacher } \\
\text { Performance } \\
\text { Correlation }\end{array}$ & 1.000 & .536 & .654 \\
$\begin{array}{l}\text { Work Motivation } \\
\text { Work Dicipline }\end{array}$ & .536 & 1.000 & .567 \\
\hline $\begin{array}{l}\text { Sig.(1-tailed) } \\
\text { Teacher } \\
\text { Performance }\end{array}$ & .654 & .567 & 1.000 \\
Work Motivation & .000 & .000 & .000 \\
Work Dicipline & .000 & & .000 \\
\hline $\begin{array}{l}\text { N } \\
\text { Teacher } \\
\text { Performance }\end{array}$ & 104 & .000 &. \\
\hline
\end{tabular}




\begin{tabular}{|l|r|r|r|} 
Work Motivation & 104 \\
Work Dicipline & 104 & 104 & 104 \\
& & 104 & 104 \\
\hline
\end{tabular}

It is known that the correlation value between teacher performance and work motivation $\left(b_{1}\right)=0.536$. Because the coefficient is close to 1 , it can be concluded that work motivation and teacher performance have a strong relationship. While the correlation between teacher performance and work discipline $\left(b_{2}\right)=0.654$. Because the coefficient is close to 1, it can be concluded that between work discipline and teacher performance has a strong relationship, the positive coefficient number indicates a positive relationship, that is, if work motivation increases, teacher performance also increases, and if teacher work discipline increases, teacher performance also increases. Furthermore, for testing hypothesis 3 with the table below.

Table 19. ANOVA table of $X_{1}$ and $X_{2}$ regression test simultaneously against $Y$

\begin{tabular}{|cc|c|c|c|c|c|}
\hline \multicolumn{1}{|c|}{ Model } & $\begin{array}{c}\text { Sum of } \\
\text { Squares }\end{array}$ & Df & Mean Square & F & Sig. \\
& & & & & \\
\hline 1 & Regression & 2407.220 & 2 & 1203.610 & 210.334 & $.000^{\mathbf{a}}$ \\
& Residual & 875.523 & 153 & 5.722 & & \\
\hline & Total & 3282.744 & 155 & & & \\
\hline
\end{tabular}

a. Predictors: (constant), work motivation, work dicipline

b. Dependent Variable: teacher performance

It can be seen that $\mathrm{F}_{\text {count }}=210.334>\mathrm{F}_{\text {table }}=3.06$ with a significance level of probability $0.000<0.05$ or sig $=0.000=0 \%<5 \%$ means reject $\mathrm{H}_{0}$ and accept $\mathrm{Ha}$, thus the regression model used for this study is significant This means that the work motivation variable $\left(\mathrm{X}_{1}\right)$ and the work discipline variable $\left(\mathrm{X}_{2}\right)$ simultaneously have a positive and significant effect on the teacher performance variable $(Y)$. The process to determine the magnitude of the influence of the work motivation variable $\left(X_{1}\right)$ and the teaching motivation variable $\left(X_{2}\right)$ on the teacher performance variable $(Y)$, namely the coefficient of determination $\left(\mathrm{R}_{2}\right)$ by looking at the R Square value in the output model summary table below.

Table 20. Simultaneous regression test for $X_{1}$ and $X_{2}$ against $Y$

\begin{tabular}{|r|r|r|r|r|r|}
\hline & Model Summary & \\
Model & \multicolumn{1}{|c|}{$\mathrm{R}$} & R Square & $\begin{array}{c}\text { Adjusted R } \\
\text { Square }\end{array}$ & $\begin{array}{l}\text { Std. Error of the } \\
\text { Estimate }\end{array}$ & $\begin{array}{c}\text { Durbin- } \\
\text { Watson }\end{array}$ \\
\hline 1 & $.856^{\mathrm{a}}$ & .733 & .730 & 2.392 & 1.710 \\
\hline
\end{tabular}

a. Predictors: (Constant), Work Motivation, Work Dicipline

b. Dependent Variable: Performance

Teacher 
It is known that the correlation value $(\mathrm{r})=0.856$ and the coefficient of determination (Adjusted R Square) $=0.733$, which means that the influence of work motivation $\left(X_{1}\right)$ and work discipline $\left(\mathrm{X}_{2}\right)$ variables on teacher performance variables $(\mathrm{Y})$ is $73.0 \%$ and the remaining $27 \%$ is influenced by other variables. Furthermore, the $t$ test is carried out according to the following table.

Table 21. Regression coefficients $X_{1}$ and $X_{2}$ against $Y$

Coefficients ${ }^{a}$

\begin{tabular}{|c|c|c|c|c|c|c|c|}
\hline \multirow[b]{2}{*}{ Model } & \multicolumn{2}{|c|}{$\begin{array}{c}\text { Unstandardized } \\
\text { Coefficients }\end{array}$} & \multirow{2}{*}{$\begin{array}{c}\begin{array}{c}\text { Standardized } \\
\text { Coefficients }\end{array} \\
\text { Beta }\end{array}$} & \multirow[b]{2}{*}{$\mathrm{T}$} & \multirow[b]{2}{*}{ sig. } & \multicolumn{2}{|c|}{$\begin{array}{c}\text { Collinearity } \\
\text { Statistics }\end{array}$} \\
\hline & B & Std. Error & & & & Tolerance & IF \\
\hline $\begin{array}{l}1 \text { (Constant) } \\
\text { Iklim_Organisasi } \\
\text { Motivasi_Mengajar }\end{array}$ & $\begin{array}{l}1.196 \\
145 \\
.379\end{array}$ & $\begin{array}{l}3.395 \\
.048 \\
.037\end{array}$ & $\begin{array}{l}.373 \\
.794\end{array}$ & $\begin{array}{l}1.236 \\
3.951 \\
10.355\end{array}$ & $\begin{array}{l}218 \\
000 \\
000\end{array}$ & $\begin{array}{l}.296 \\
.296\end{array}$ & $\begin{array}{l}.374 \\
.374\end{array}$ \\
\hline
\end{tabular}

a. Dependent Variable: Teacher Performance

The value of work motivation and discipline of 0.951 at 10.355 . The significance of the work motivation variable is 0.343 and work discipline is 0.000 . The value of $t$ table with $\mathrm{n}=150(\mathrm{dk}=\mathrm{n}-2)$ is 1.960 . Using the $\mathrm{t}$ value table and the significance limit of 0.05 , it is known that the $t$ count of the two variables is greater than the $t$ table and the significance of the two variables is $<0.05$. So it can be concluded that work motivation and work discipline together have a significant effect on teacher performance.

Next, determine the regression equation between the work motivation variable $\left(X_{1}\right)$ and the work discipline variable $\left(\mathrm{X}_{2}\right)$ on the teacher performance variable $(\mathrm{Y})$. Based on table above, it is known that the constant value (a) is 1.196 and the regression coefficient of work motivation $\left(b_{1}\right)$ is 0.145 and work discipline $\left(b_{2}\right)$ is 0.379 . So the regression equation can be written: $\mathrm{Y}=1.196+0.145 \mathrm{X}_{1}+0.379 \mathrm{X}_{2}$.

Based on the above equation, it is known that the constant value is 1.196 , so if the variable work motivation $\left(X_{1}\right)$ and work discipline $\left(X_{2}\right)$ are together the value is 0 , then the teacher's performance is 1.196 . The regression coefficient of work motivation is positive, namely 0.145 , meaning that each increase or decrease in work motivation in every one unit, will increase or decrease the teacher's performance by 0.145 units, assuming the variable value of work discipline is fixed. While the coefficient of work discipline is 0.379 , meaning that each increase or decrease in work discipline every one unit, will increase or decrease the teacher's performance by 0.379 units, assuming that the value of the work motivation variable is fixed. The positive value contained in the independent variable regression coefficient (work motivation and work discipline) illustrates that the direction of the influence on the dependent variable (teacher performance) is unidirectional.

Thus the research findings on the effect of work motivation and work discipline on the performance of elementary school teachers in Gugus IV Diponegoro, Lengkiti District are briefly as follows.

a. Work motivation has a positive and significant effect on teacher performance by $54.3 \%$.

b. Work discipline has a positive and significant effect on teacher performance by $73.2 \%$.

Work motivation and work discipline together have a positive and significant effect on teacher performance by $73.0 \%$. 


\section{Discussion}

Based on respondents' perceptions, namely elementary school teachers in Gugus IV Diponegoro, Lengkiti District, about teacher performance, obtained a score range of 41-60, with a total score of 7918 and the average score obtained by respondents is 53.76 which in this case is categorized as good.

The results of factor analysis for teacher performance variables obtained the highest average score is the dimension of "learning planning" of 739. This shows that teacher performance seen from the dimensions of learning planning is good because the teacher can prepare a lesson preparation plan well, the teacher can make Prota and promissory notes, the teacher has made a good syllabus. While the lowest average score is the dimension of the "learning process" of 675 . This shows that the teacher's performance in the learning process is still not optimal, namely by the learning objectives, motivating students, teaching with appropriate methods and strategies and implementing learning procedures. as planned. Fairly good teacher performance will result in student learning achievement that is quite good. Furthermore, a fairly good teacher performance can be seen from the results obtained from the student achievement appraisal.

In addition to learning planning, the learning implementation process, and learning evaluation, teacher performance is assessed in implementing the learning process. A learning process is a form of implementing learning that is given by the teacher to students.

Several variables are thought to affect teacher performance, including work motivation and work discipline. From the research results related to this, the findings are obtained, the results of which we will discuss below.

\section{The Effect of Work Motivation on Teacher Performance}

Based on the respondents' perceptions of work motivation, a score range of 116-150 is obtained, with a total score of 20409 and an average score of 130.79 which in this case is categorized as quite good. Seven dimensions of work motivation which include indicators: responsibility, sense of belonging, warmth, support, conflict, appreciation and commitment. The dimension/indicator that received the lowest score was "support", which is a total score of 372 .

As for the dimension/indicator of "warmth", the highest score was 966. This can be a concern for the head of madrasah/school as a supervisor to create work motivation in school/madrasah towards teachers by using the right approach and approach techniques so that in implementation it can run effectively so it can help teachers to improve the quality of their performance. Furthermore, the principal is expected to have a good warmth in implementing an agenda as a follow-up to creating a school/madrasah climate so that it can achieve the right goals/targets.

Work motivation is a physical and non-physical working condition of the work environment that influences behaviour and is a motivational factor that needs the attention of every leader in the organization. This is by the research of Hasanah et al (2010) entitled "the effect of teacher leadership education and work climate on the performance of elementary school teachers in Babakancikao District, Purwakarta Regency". In journal of educational research journal Vol.11 no. .2, October 2010. From the analysis, it was found that the influence of teacher leadership training $\left(X_{1}\right)$ on teacher performance $(Y), r^{2}$ contributed $11.4 \%$. Work climate $\left(\mathrm{X}_{2}\right)$ on teacher performance $(\mathrm{Y})$ was obtained $47.2 \%$. How much influence is the training of teacher leadership and work climate on teacher 
performance $\mathrm{R}^{2}=0.573$. This means that it contributed to $57.3 \%$. In other words, the increasing number of teacher leadership training sessions and the improving teacher working climate resulted in increased teacher performance.

The implication of the results of this study requires that principals who have carried out supervisory activities properly so far need to be maintained and even need to improve/develop possible efforts to further improve the quality of teacher performance. Based on the findings of this study, through a regression test, it is known that the effect of work motivation on teacher performance is $54.3 \%$. This proves that the effect of work motivation on teacher performance, especially elementary schools in Gugus IV Diponegoro, Lengkiti District, is quite good. Thus it can be explained that work motivation can influence, encourage, guide, direct and mobilize all teachers to carry out their duties in managing effective learning.

Based on respondents' perceptions, relevant previous research and the findings of this study through regression tests, it can be stated that work motivation has a positive and significant effect on the performance of elementary school teachers in Gugus IV Diponegoro, Lengkiti District, can be justified.

\section{The Influence of Work Motivation on Teacher Performance}

Based on respondents' perceptions about the effect of work discipline on teacher performance, the score ranges from 107 to 151, with a total score of 20191.00 and an average score of 134.43 are in a good category. Of the eight dimensions of work motivation variable indicators which include: (a) advancement, (b) individual recognition, (c) job security, (d) leadership loyalty, (e) job security, (f) achievement, (g) promotion, (h) salary / wages. Respondents gave the highest score for the dimension of "individual recognition" and the lowest score on the dimension of "leadership loyalty". Thus, it should be the main thing for all teachers to improve the ability of teachers to use learning media tools to improve the quality of learning.

According to Siagian concludes that: motivation as the whole process of giving work motives to innate people in such a way that they want to work sincerely to achieve organizational goals effectively and efficiently, that motivation is energy to generate encouragement from within the teacher that influences, awakens, directs and maintaining behaviour related to the work environment, so motivation is the motivation from the teacher to meet the stimulation needs-oriented towards individual goals in achieving a sense of satisfaction, then implemented to others to provide good service to the community.

The main basis for the implementation of motivation by a leader is knowledge and attention to human behaviour that he leads as a determining factor for organizational success which views humans as a determining factor for success which means also serious attention to all problems of need. A leader who is successful in carrying out the function of motivation is a leader who can realize the synchronization between the personal goals of the members of the organization and the personal goals of the members of the organization with the goals of the organization itself.

The findings through regression test showed that the degree of influence of the work motivation variable on the performance of elementary school teachers in Gugus IV Diponegoro, Lengkiti District was 0.732 or $73.2 \%$, the remaining $26.8 \%$ were influenced by other factors. This is in line with the results of Carudin (2011) 's research, entitled "the influence of principal leadership and school work climate on Teacher Performance". From the calculation results, the work motivation variable partially or simultaneously has a 
significant influence on teacher performance. The effect of work motivation $\left(X_{1}\right)$ and teacher performance $\left(\mathrm{X}_{2}\right)$ on teacher performance $(\mathrm{Y})$ is shown by the simultaneous correlation coefficient $(\mathrm{R})$ of 0.388 with a coefficient of determination of $15.1 \%$. Simultaneously, the principal leadership and the school work climate also determine the teaching performance of teachers by $15.1 \%$ and the remaining $84.9 \%$ are influenced by other factors.

Based on the respondent's perception, relevant previous research, as well as the findings through the regression test in this study, it can be stated that work discipline has a positive and significant effect on the performance of elementary school teachers in Gugus IV Diponegoro, Lengkiti District.

\section{The Effect of Work Motivation and Work Discipline Together on Teacher Performance}

The degree of influence of the work motivation variable $\left(X_{1}\right)$ and the work discipline variable $\left(\mathrm{X}_{2}\right)$ on teacher performance $(Y)$ was 0.73 or $73 \%$. This figure shows that the teacher's performance $(\mathrm{Y})$ is jointly (simultaneously) influenced by the work motivation variable $\left(X_{1}\right)$ and the work discipline variable $\left(X_{2}\right)$ by $73.0 \%$ while the remaining $27 \%$ is influenced by other factors outside the equation model.

This is in line with the results of the research conducted by Pujiyanti \& Isroah (2012) entitled, "the effect of work motivation and work discipline on teacher performance in SMA Negeri 1 Ciamis. The results of this analysis support the hypothesis that work motivation and discipline working with the same positive effect on the performance of teachers, as shown by the price of $R_{\text {count: }} .938, F_{\text {count: }} 216.172$ and $R_{2}$ of: 0,880 which means that the variation of increase or decrease in performance teachers are influenced by work motivation and work discipline variables of 0.880 and the remaining $12.0 \%$ are influenced by other variables not examined.

The work motivation created by the principal can be formulated as a series of efforts to provide assistance to teachers in the form of professional services provided by the principal in order to improve the quality of teaching and learning processes and outcomes in addition to the organizational climate, work motivation also has a major influence on teacher performance.

Based on the research findings and from previous research, it can be concluded that there is a positive and significant influence between work motivation and work discipline together on the performance of elementary school teachers in Gugus IV Diponegoro, Lengkiti District.

\section{Conclusion}

Based on the results of research through data analysis, hypothesis testing and discussion, it can be concluded that:

1. There is a significant relationship between work motivation $\left(X_{1}\right)$ and teacher performance $(Y)$. There is a relationship between work motivation $\left(X_{1}\right)$ and teacher performance $(\mathrm{Y})$ with an $\mathrm{R}$ value of 0.546 because the multiple correlation value is between $0.40-0.984$. From the simple linear regression equation, a positive coefficient is obtained, meaning that there is a positive relationship between the work motivation variable $\left(\mathrm{X}_{1}\right)$ and teacher performance $(\mathrm{Y})$, the higher the school work motivation, the higher the performance of elementary school teachers in Group IV Diponegoro In addition, work motivation variable as the independent variable 1 
impact on teacher performance of $96.8 \%$, as evidenced by the value of the coefficient of determination $\left(\mathrm{R}_{2}\right)$ which indicates the number 0.968 or $96.8 \%$.

2. There is a significant relationship between work discipline $\left(X_{2}\right)$ and teacher performance variables $(\mathrm{Y})$. The coefficient is positive on the results of linear regression, meaning that there is a positive relationship between work motivation and teacher work discipline. So the better the work motivation, the better the work discipline of the Diponegoro cluster IV elementary school teachers. The correlation between work discipline $\left(\mathrm{X}_{2}\right)$ on teacher performance variables $(\mathrm{Y})$ is 0.732 . Since the multiple correlation value is between $0.02-0.399$, it can be concluded that there is a low relationship between work discipline $\left(\mathrm{X}_{2}\right)$ and teacher performance $(\mathrm{Y})$. The coefficient of determination $\left(R_{2}\right)$ is equal to 0.150 or $15 \%$. This means that the percentage contribution of the influence of the work motivation variable as independent variable 2 on teacher work discipline has an effect of $15 \%$.

3. There is a significant relationship between work motivation $\left(X_{1}\right)$ and work discipline $\left(\mathrm{X}_{2}\right)$ on the teacher performance variable $(\mathrm{Y})$ SD Group IV Diponegoro. There is an adequate relationship between work motivation and work discipline on teacher performance with an $\mathrm{R}$ value of 0.856 . From the multiple linear regression equation, the coefficient value is positive, meaning that there is a positive relationship between work motivation and work discipline with teacher performance. The percentage of the contribution of the influence of the work motivation variable $\left(X_{1}\right)$ and work discipline $\left(\mathrm{X}_{2}\right)$ on the teacher performance variable $(\mathrm{Y})$ was $27.5 \%$. While the remaining $72.5 \%$ is influenced by other variables that are not included in this research model. So, work motivation and work discipline have a significant relationship with the performance of elementary school teachers in Gugus IV Diponegoro. The better the application of work motivation in carrying out their roles and duties, and always increasing attention in motivating teachers to work, will increase teacher work discipline as well. It is hoped that the increasing work discipline of the Diponegoro cluster IV elementary school teachers will also have an impact on increasing teacher work motivation, so that educational goals are achieved effectively and efficiently.

\section{Reference}

Almasri, M.N. (2016). Manajemen Sumber Daya Manusia: Imlementasi Dalam Pendidikan Islam. Kutubkhanah: Jurnal Penelitian Sosial Kegamaan, 19 (2), pp. 133 151. http:/ / ejournal.uin-suska.ac.id/index.php/Kutubkhanah/article/view/2547
Budiman, H. (2017). Peran Teknologi Dan Komunikasi Dalam Pendidikan. Al-Tadzkiyyah: Jurnal Pendidikan Islam, 8 (1), pp. 31-43. http://103.88.229.8/index.php/tadzkiyyah/article/view/2095

Ideswal, I., Yahya, Y., \& Alkadri, H. (2020). Kontribusi Iklim Sekolah dan Kepemimpinan Kepala Sekolah Terhadap Kinerja Guru Sekolah Dasar. Jurnal Basicedu, 4 (2), pp. 460-466. https:// doi.org/10.31004/ basicedu.v4i2.381

Juniarti, E., Ahyani, N., \& Ardiansyah, A. (2020). Pengaruh Kepemimpinan Kepala Sekolah dan Disiplin Guru Terhadap Kinerja Guru. Journal of Education Research. 1 
(3), pp. 193-199. https:// doi.org/10.37985/joe.v1i3.21

Kemal, I., \& Rahmatullah. (2015). Analisis SWOT Sekolah Tinggi Keguruan dan Ilmu Pendidikan STKIP Bina Bangsa Getsempena Banda Aceh. Jurnal Visipena, 6 (1), pp. 122-132. https://doi.org/10.46244/visipena.v6i1.361

Kemal, I., Suryadi., \& Rosyidi, U. (2019). Management of Lecturers Resource Development at Higher Education. International Journal of Higher Education, 8 (5), 246-256. https:// doi.org/10.5430/ijhe.v8n5p246

Kurniah, A., Patawari, P., \& Nongkeng, H. (2019). Pengaruh Gaya Kepemimpinan Kepala Sekolah dan Lingkungan Kerja Sekolah Terhadap Motivasi Kerja Guru MA Ihya'Ulumiddin Kampung Beru Kabupaten Bantaeng. Economy Deposit Journal, 1 (1), pp. 41-48. https:/ / uit.e-journal.id/EDJ/article/view/200

Maujud, F. (2018). Implementasi Fungsi-Fungsi Manajemen Dalam Lembaga Pendidikan Islam (Studi Kasus Pengelolaan Madrasah Ibtidaiyah Islahul Muta'alim Pagutan). Jurnal Penelitian KeIslaman, 14 (1), pp. 30-50. https://doi.org/10.20414/jpk.v14i1.490

Nasution, H., \& Aliffioni, A. (2018). Analisis Efektivitas Penagihan Pajak Dengan Surat Paksa Dan Penyitaan Untuk Meningkatkan Penerimaan Pajak Pada Kantor Pelayanan Pajak Pratama Bekasi Utara. Jurnal Ilmiah Wahana Akuntansi, 13 (2), pp. 129-142. https:/ / doi.org/10.21009/wahana.13.023

Permanasari, R. (2013). Pengaruh Motivasi Dan Lingkungan Kerja Terhadap Kinerja PT. Augrah Raharjo Semarang. Management Analysis Journal, 2 (2), pp. 1-9. 10.15294/MAJ.V2I2.2493 